\title{
An interlocked oscillator model for firing of the mesencephalic dopaminergic neuron
}

\author{
Joon $\mathrm{Ha}^{*}$, Alexey Kuznetsov \\ From Nineteenth Annual Computational Neuroscience Meeting: CNS*2010 \\ San Antonio, TX, USA. 24-30 July 2010
}

Dopaminergic (DA) neurons display two functionally distinct modes of electrical activity: low- and highfrequency firing. We suggest a new minimal computational model that unites data on these firing modes obtained under different experimental conditions. The model reproduces the separation of maximal frequencies under NMDA synaptic stimulation vs. other treatments. In accord to recent experimental data, NMDA stimulation restricted to the soma effectively evokes high-frequency oscillations in the model. We have also reproduced low- and high-frequency oscillations under blockade of the SK current. Thus, the new model suggests a way that overcomes all major limitations of the switching dominance mechanism for controlling the frequency of the DA neuron. We explain recent experimental facts and make further predictions.

Published: 20 July 2010

doi:10.1186/1471-2202-11-S1-P151

Cite this article as: $\mathrm{Ha}$ and Kuznetsov: An interlocked oscillator model for firing of the mesencephalic dopaminergic neuron. BMC Neuroscience 2010 11(Suppl 1):P151.

* Correspondence: jha@math.iupui.edu

Department of Mathematical Sciences, Indiana University Purdue University Indianapolis, Indianapolis, IN, 46202 USA

Submit your next manuscript to BioMed Central and take full advantage of:

- Convenient online submission

- Thorough peer review

- No space constraints or color figure charges

- Immediate publication on acceptance

- Inclusion in PubMed, CAS, Scopus and Google Scholar

- Research which is freely available for redistribution

Submit your manuscript at www.biomedcentral.com/submit
C Biomed Central 